\title{
Collision of Indian Plate and Indus Tsangpo Suture Zone: Some Geological Constraints
}

\author{
Zahid Ali Khan ${ }^{1,}$, Ram Chandra Tewari ${ }^{2}$, Rabindra Nath Hota ${ }^{3}$ \\ ${ }^{1}$ Directorate of Geology and Mining, Khanij Bhawan, Lucknow, India \\ ${ }^{2}$ Department of Geology, Sri Jai Narain P. G. College, Lucknow, India \\ ${ }^{3}$ Department of Geology, Utkal University, Bhubaneswar, Odisha, India
}

Email address:

zahid26aug@yahoo.co.in (Z. A. Khan),ram.tewari9@gmail.com (R. C. Tewari), rnhota@yahoo.com (R. N. Hota)

${ }^{*}$ Corresponding author

\section{To cite this article:}

Zahid Ali Khan, Ram Chandra Tewari, Rabindra Nath Hota. Collision of Indian Plate and Indus Tsangpo Suture Zone: Some Geological Constraints. Earth Sciences. Vol. 6, No. 4, 2017, pp. 51-62. doi: 10.11648/j.earth.20170604.12

Received: July 26, 2017; Accepted: August 8, 2017; Published: August 17, 2017

\begin{abstract}
The occurrence of Gondwana affinity Permo-Carboniferous glacial deposits in northern Tibet, Lhasa Block and Qiangtang Block obviously suggests that India continued into Tibet at that time. Significant also is that paleoclimatic continuity was maintained over landmass of India and Tibet from Paleozoic through the Cenozoic eras up to the Pleistocene. The age and origin of the Indus-Tsangpo Suture (ITS) is doubtful because the ophiolites are about 100 Ma older than the supposed collision. Similarly, the progressive under-thrusting of the Indian plate below the Tibetan plate is deemed unlikely, as the ophiolites must have formed an $8-20 \mathrm{~km}$ thick wall between the two plates and it was not possible for the Indian Plate to cross it. Probably the apparent northward migration of India indicates a northward migration of the North Pole. Similarly, there is no explanation for the fact that, if underthrusting has taken place, why did the Himalayan uplift occur some $500 \mathrm{~km}$ from the Indus-Tsangpo suture instead of being along the collision zone itself, negate under thrusting. The double thickness of the crust in Tibet is not a unique feature in that it continues south of the so-called Indus-Tsangpo suture, as also in the Pamir; it is of about the same order in the Andes. Whereas the Tibetan glacial indicate that India and Tibet were not separated in the Carboniferous, Lystrosaurus fauna suggests it for the Lower Triassic and the ophiolites for the Jurassic-Cretaceous. The development of rift valleys and normal faults cutting across the Indus-Tsangpo suture (ITS) shows that even in the Quaternary India and Tibet was together. Indeed, the measured Cambrian diameter is $50 \%$ of the Earth where as in Upper Permian it was about 55-60\% with the North Pole near Verkhoyansk and the South Pole to the southeast of South Africa. Evidently the Earth is expanding and the rate of expansion has progressively accelerated through time is supported by decline in the gravitational constant from about one third to about one half of the present from Precambrian up to Mesozoic.
\end{abstract}

Keywords: Tibetan Glacial Deposits, Indus-Tsangpo Suture, Plate Tectonics, Polar Wandering, Paleopole, Paleogravity and Earth Expansion

\section{Introduction}

[1], in 'Our Wandering Continent' reconstructed the continental landmasses in the Permian and proposed independent Gondwanaland in the southern hemisphere, whereas the northern hemisphere was occupied by Laurasia, and perhaps, the two more continents, Angaraland and Cathaysia. Tethys occupied the area in between the northern and southern landmasses. The proposal was based on the Gondwanaland glaciations, the Gondwana fauna and particularly the endemic and unique flora. Consequently, the Permian ice cap covering almost the entire supercontinent (figure 1), should have been three or four times of the present Antarctic ice cap which would have been impossible without intense ice age and profound lowering of the Earth's temperature. Yet the warm climate fauna from Europe and North America suggests that a normal, if not actually warmer than the present, climate prevailed over the Earth and the immense ice covered area of the Gondwana supercontinent calls for a suitable explanation. 


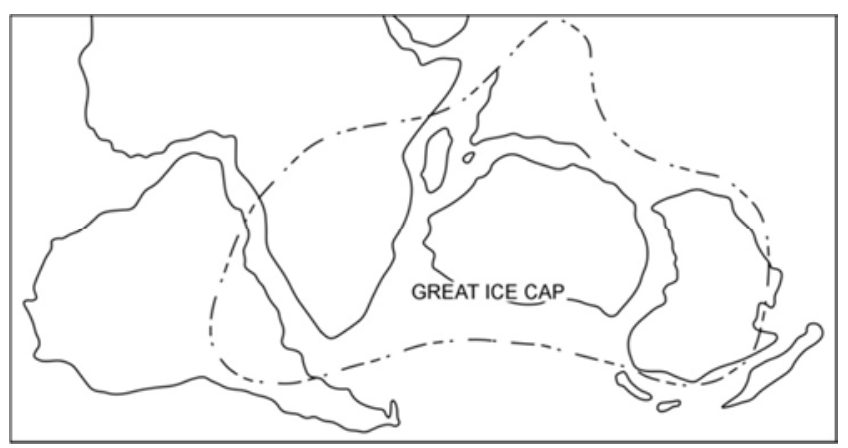

Figure 1. Map showing the area glaciated during the Gondwana glaciations [1].

[2] Suggested that it was the consequence of an exceptionally rapid polar wandering (figure 2), with the ice cap remaining more or less of normal size all the time. The subsequent discovery of extensive Ordovician striated pavement across the Sahara and the inferred Siberian and Cambrian glaciations in the west and northwest Africa further strengthened the polar wandering concept. Although this approximate polar wandering path for the South Pole appeared to be reasonable; the corresponding path for the North Pole should be identical in shape, but has been evading the scientific community. This is perhaps because it must have been in the terra incognita to the north of Canada. Unless the North polar migration is worked out specifically and is found to differ from Ahmad's path, the latter should be accepted as it is well documented. The above concept of independent Gondwanaland (southern) and Laurasia (northern) supercontinents caught the attention of most Gondwana geologists, as also of many in England and parts of Europe, although the Americans rejected the continental drift concept. However, of late, there were evidences to question the hypothesis, though the American school latter currently accepted that continents have moved from their original position.

The theme of present paper is to place on record various geological, paleontological, paleoclimatic and paleogeographic constraints in relation to independent Gondwanaland, northward migration of Indian plate, and collision and under thrusting.

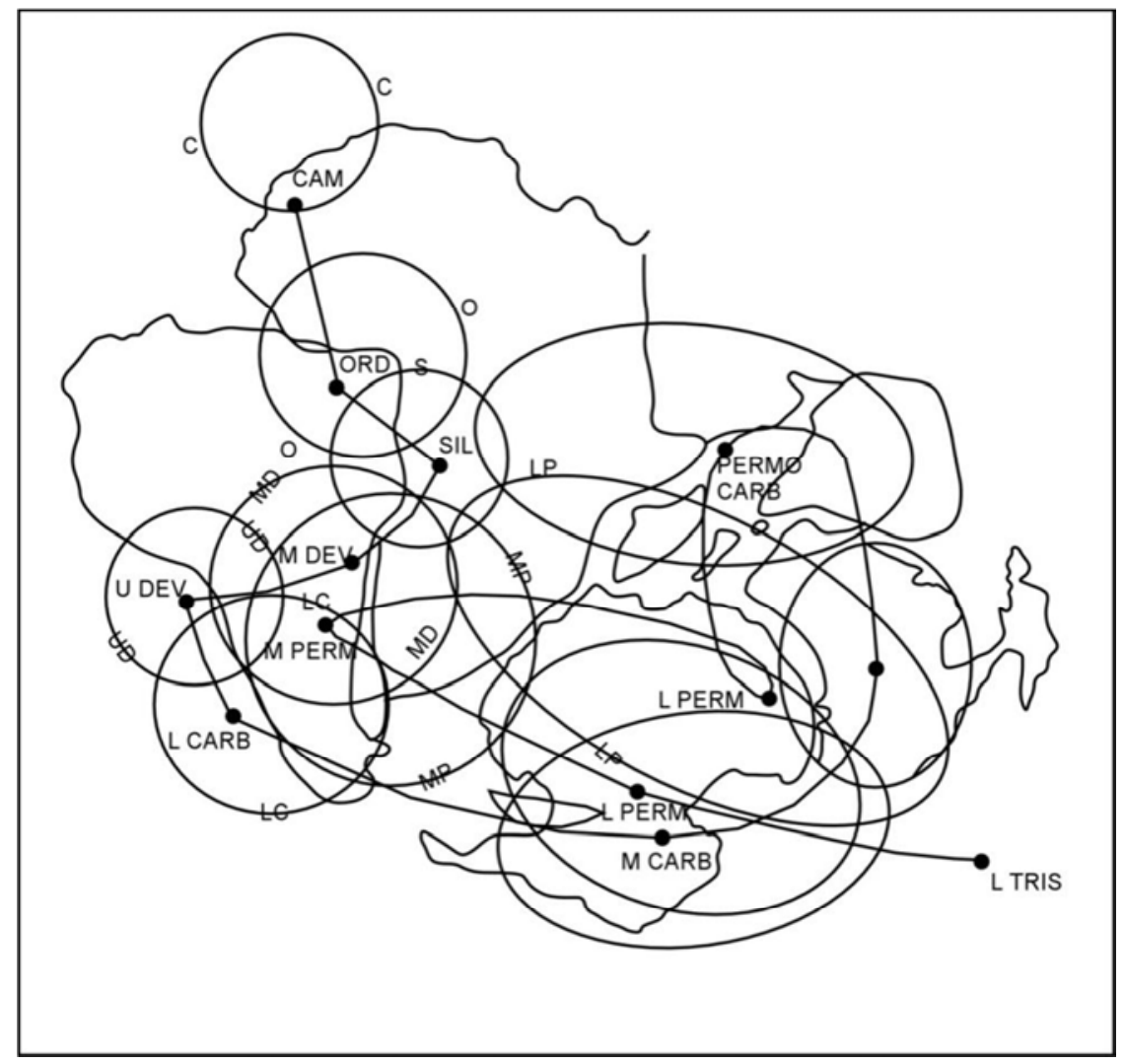

Figure 2. Polar wandering path of [2], re-plotted on a different Gondwana assembly.

\section{Geological Constraints}

\subsection{Tibetan Glacial Deposit}

The important discovery is the occurrence of PermoCarboniferous marine glacial deposits in northern Tibet and adjoining areas $[3,4,5$, and 6]. It was already known from western Afghanistan, Myanmar, and Spiti and was soon after reported from three localities in southern Saudi Arabia. However, the first casualty with Tibetan and Yunnan discovery was [1]'s reconstruction of Gondwanaland, for it became inconceivable without India having been an integral part of Pangaea in its present location and relationship with Afghanistan, Tibet and Myanmar. There was, thus, no place for an independent super-continent in the southern hemisphere. Chinese geologists have reported various aspects 
of the $1600 \mathrm{~m}$ thick deposit that covers an area of thousands of sq. $\mathrm{km}$. extending from north of Lhasa to Kun Lun mountains in northern Tibet $[5,6,7,8]$. Indeed, it underlies every Permo-Carboniferous beds and carries striated boulders as well as erractics of up to $5 \mathrm{~m}$. In addition, there is evidence that the glacial debris was transported from south to north, obviously from India $[9,10]$. Tibet, then, must have been in the temperate latitudes of the southern hemisphere. The deposits carry Gondwana affinities flora including Stepanoviella, Noeggerathiopsis, Gangamopteris, Equisetalean, and, locally, the Glossopteris [3, 5, 11] and associated palynomorphs [12]. The plant assemblage strongly recalls the Early Permian Lower Gondwana Talchir Flora of the Indian subcontinent. [13] Correlated these deposits with the Blaini glacial of the Himalayas, and suggested that the glacial had moved from south to north and carried Gondwana fauna. The South Pole of that time was, apparently, located in Peninsular India, and the ice cap extended to around the area presently occupied by the Vindhyan plateau. Glaciers must have been transporting the tillite material northward to the area presently occupied by the Himalayas. An epicontinental Tethys extended from there northward, to the southern margin of the Siberian territory; and icebergs were transporting the material over to this area. The icebergs reached northern Tibet and melted depositing entire load over the Tibetan territory. The amount of glacial material transported is immense indicating that the ice cap was in Peninsular India for a long time.

[14], [15] admitted that the glacial deposits in northern Tibet are a 'serious constraint to plate tectonic speculations'. Later on, [16], [15] described these glacial deposits as 'rift in-fills' denying existence of the glacial deposit as also the flora and fauna of Gondwana affinities. Apart from all their inherent character how could rift in-fills be spread all over northern Tibet (emphasis by present authors) to underlie every exposure of Permo-Carboniferous beds? Rifts are long, narrow features and even hundreds or thousands of the rift valleys could not have covered such an extensive area. This indeed is travesty, and the stand is taken to fit the plate tectonic data which the available field evidences unequivocally contradicted. The evidence thus supports that these glacial deposits were formed by icebergs traveling across an epicontinental sea from northern India to near the Kun Lun Range. The glaciers emanated from the ice-cap should have produced deep channels in the area between the ice-cap and the Tethys, and as the ice-cap receded westward the marine fauna traveled up through these channels. Paleoflow studies [10, 17] indicate that the sediment transport was towards the northwest, and it was possible that the life forms traveling up this glacial cut deep bed and preserved in Umaria and Manendragarh, Central India, whereas in the Damodar Valley in eastern India at Rajhara may have a different channel. The area covered by the icecap must have rebounded once the weight of the ice-cap was removed, a natural phenomenon. The incursive sea must, therefore, have been rather ephemeral and hence the fossil beds are thin and more or less local [18]. Most of this drainage must have been flowing into the Tethys to the north [19], many emanating from glaciers continuing the ice cover. It may, moreover, be emphasized that peninsular India was then down wrapped by the weight of the ice and facilitated the sea incursion. Many of the freshly emerging drainage channels must have discharged into this ephemeral sea; the drainage system indicated in the Gondwana sediments came in at a later stage and later reversed to form the present drainage.

\subsection{Indus Tsangpo Suture Zone}

In Indian context, the plate tectonic hypothesis is wedded on the concept of collision between Indian Plate and the Tibetan Plate along Indus-Tsangpo Suture Zone [20, 21, 22] (figure 3).

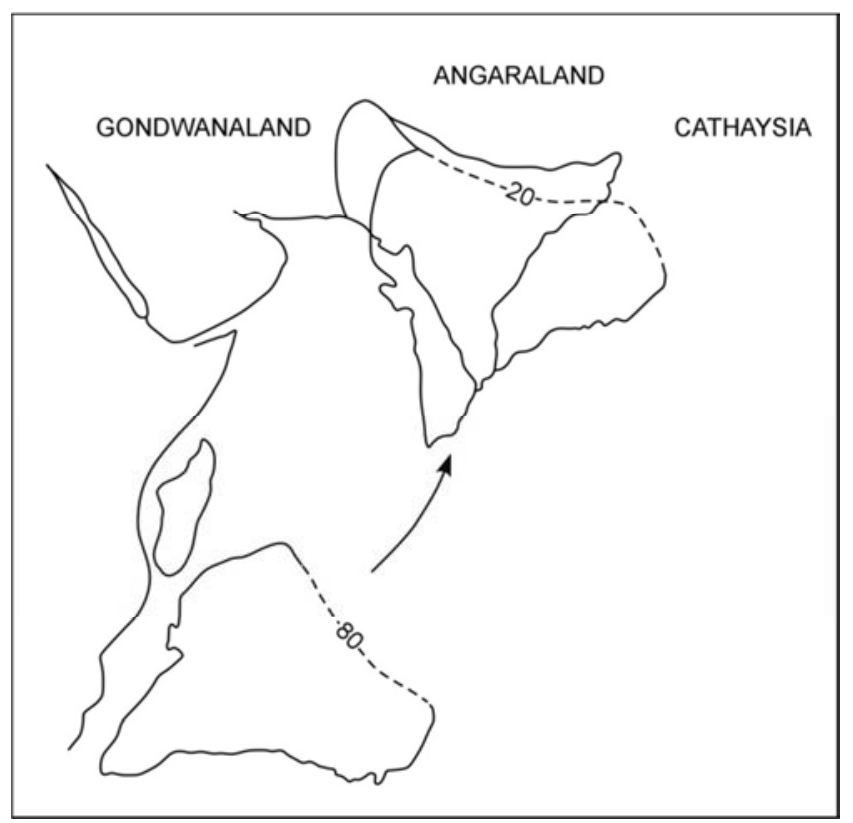

Figure 3. India having migrated from the southern hemisphere rejoined northern Gondwanaland on the northwest, Angaraland on the north and Cathaysia on the northeast. This junction line should exist all along from the Arabian Sea to Bay of Bengal.

Of the particular interest in this regard is the age of the ophiolites occurring within the suture during sea floor obduction. Ophiolite should be of the age of the collision considered to be Oligocene-Miocene and the ophiolites should have come in a single episode. However, these ophiolites are of two distinct ages, Upper Jurassic - Lowest Cretaceous, and little younger in Lower Cretaceous implying that the ophiolites and the so-called suture zone existed, about a hundred million years before the supposed collision. These two ophiolites have contact metamorphosed the host rocks on both the sides and their own margins are distinctly chilled. The second emplacement has solidified as pillows, and has sills cutting through dykes and sills alike. The bulk of the ophiolite is essentially represented by a mantle sequence, which comprises harzburgite, dunites and chromitites. The chromitites host a variety of ultra high pressure minerals such as diamonds, moissanite, native metal 
and PGE alloys indicate that it originated at a temperature of $1105-1240^{\circ} \mathrm{C}$ and a pressure of $27-46 \mathrm{kbar}$, confirming to a depth of $80-140 \mathrm{~km}[23,24]$ Also, crystal settling in this emplacement is extensive and has resulted in acid rocks near the top and ultra basic near the bottom of every exposure. Moreover, [25] admitted that the ophiolites are in fact similar to tholeiites formed in mid-ocean ridge spreading area i.e. they are not oceanic crust emplaced in the process of collision, but are magma upwelling from the mantle. These characteristics suggest that the lava was in a highly molten state, and must have originated at the indicated depth. Indeed such features are not possible to result in an obducted ocean floor, and, hence, the so-called suture zone may represent an imagination. It carries features of a deep fault through which magma may have come up. Moreover, geological investigations in the so called 'Indus Suture Zone' indicate that it is, in fact, a rift valley and its continuation in Tibet interpreted as an extensive syncline. Similarly, the 'IndusTsangpo Suture' terminates abruptly in Jurassic phyllites, intruded by Tertiary granites at Rinbun, southwest of Lhasa north of Myanmar (figure 4) and there is no trace of it farther east.

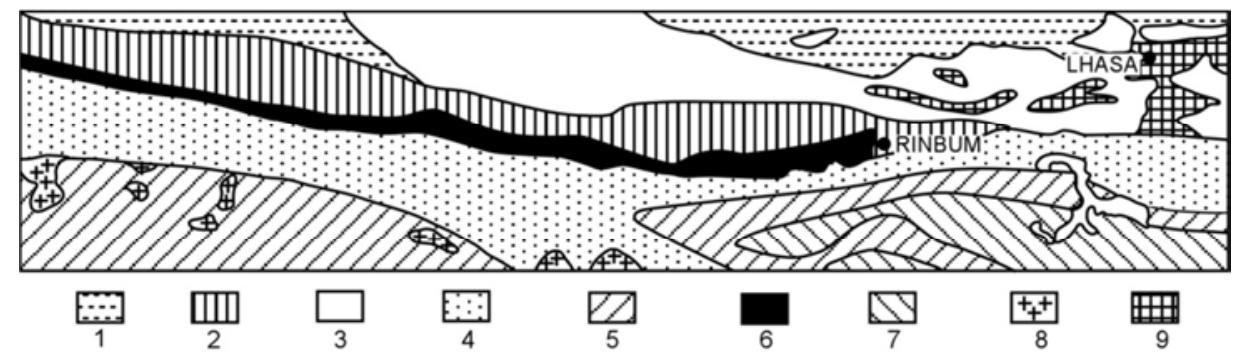

Figure 4. The Indus-Tsangpo Suture Zone. This feature contains the emplaced igneous rocks within its two faulted rocks and end abruptly at Rinbun. East of it there is no trace of it. 1. Lingzizang Formation; 2. Xigaze Group; 3. Gangdise Belt; 4. Triassic Flysch; 5. Jurassic Slates; 6. Ophiolite; 7. Cretaceous Sediments; 8. Himalayan Granites; 9. Lhasa granite.

Further there is no explanation as to what happened to the ocean floor that must have existed in front of the Assam and Myanmar parts of the Indian Plate. Thus, the so-called suture dies out in a rock formation much older than the supposed collision and suturing. In fact, during the Jurassic India should have been in the southern hemisphere accepting the plate tectonics model. Interestingly, three other suture zones, Bongong-Nujiang, Jinshajing-Tungbianhe (Kokoxilo) and Jinsha-Tongbian (Lilien) (Figure 5) have been reported from Tibet, and are progressively older northward. [26] noted that each suture basically associated with granitic intrusive which are oldest in the north (344-354Ma in Altyn-Tagh) and youngest in the south (10-75 Ma in the Greater Himalaya).

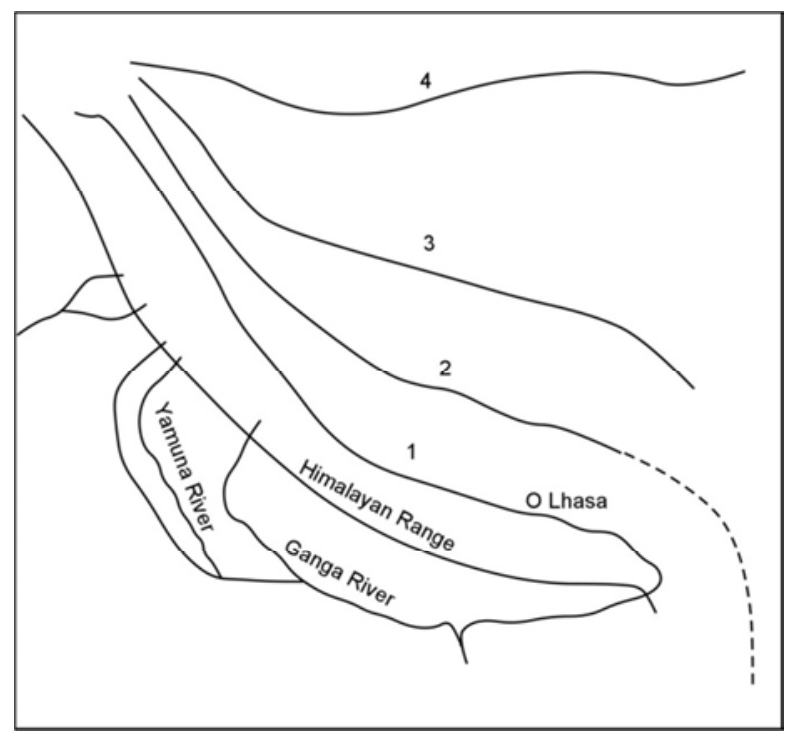

Figure 5. North of the Indus-Tsangpo Suture there are three other major identical features. 1. Indus-Tsangpo Suture; 2. Bongong-Nujiang Suture; 3. Kokoxilo Suture; 4. Lilien Suture.
These authors, therefore, believed that the Tibetan plateau and the Himalayan ranges resulted from a crustal shortening amounting to about $500 \mathrm{~km}$ along a series of four successive subduction zones or suture beginning in the north and migrating southwards. However, subsequent works on radiometric dating show that much older igneous intrusions are present in the south as well as in the north [21, 27], Moreover, all blocks in Tibet show structural unity from Late Proterozoic to the Tertiary, which is contrary to the [26] model. It is believed that the Indian plate separated repeatedly from the northern landmass, and then returned to rejoin it. [28], however, denied these repeated detachments and northward drifts of the Gondwanaland fragments. [29] based on filed observations and petrographic studies deny the presence of ophiolite suite, too, insists that the occurrences of blueschists in ophiolite mélange are not related to subduction and therefore they cannot be used as evidence of a suture zone.

On the other hand, the thrusting of the Indian Plate underneath the Tibetan plate is well documented by paleomagnetic data $[30,31,32,33]$ and providing strength for the plate tectonic concept. However, as soon as the collision had taken place, the ophiolites erupted and should have formed a vertical wall of about $8-20 \mathrm{~km}$. thick hard rock between the two plates and it was perhaps not possible for the Indian Plate to pass through it to thrust under the Tibetan Plate, and to go on progressively since then. Alternatively, it seems more appropriate that the Indian rocks have truthfully recorded the northward migration of the North Pole and it is unfortunate that corresponding data are not available from African rocks or from those of other neighboring continents. Had the Indian Plate been thrusting underneath the Tibetan Plate, earthquakes would have been common over the plateau and frequent along the suture 
zone. Since the conclusion of progressive under-thrusting is based on paleomagnetic data derived from Indian rocks, it is possible that the northward movement of the North Pole is being interpreted as the northward movement of the Indian plate. Secondly, paleomagnetic poles determined from continental basalts and from oceanic magnetic anomalies of the same age fall apart, by as much as 2000 $\mathrm{km}$, raising doubts about the very tenets of plate tectonics or inadequacies in data quality or suggesting that the paleomagnetic principle is not applicable in interpretation of plate motions. Therefore, the hypothesis of any northward movement of India and its progressive underthrusting the Tibetan Plate, therefore, lacks scientific basis.

\subsection{Paleogeographic Evidence}

[34] paleogeography of the Tethys region during Carboniferous, Permian, Triassic and Jurassic suggested general absence of an ocean in the region; geosynclines existed with entirely different sediments. Obviously, an epicontinental sea existed in the area, but it would mean that continental crust extended from one end to the other. This vast sea extended from the Pacific coast to China to Spain and thereafter via Appalachian basin to the Pacific coast of Mexico, except perhaps in the Carboniferous, an ephemeral land bridge existed from Kashmir to eastern Russia via the Aral Sea. The same bridge divided Tethys into the two parts and is testimony to the significant differences in the fauna of the two regions. Greater India, at that time, was largely a positive area as a part of the Supercontinent, Pangaea, and contributed to the sediments being deposited in the Tibetan area of the Tethys. The paleogeographic maps of the given region by [35] do not corroborate either Plate Tectonic concept or the Earth expansion model because the area north of the Himalayas was undoubtedly, marine and are dominated by shallow-water carbonates, quartzite and shale $[36,34]$ additionally pointed out that the Tibetan Shield, however, continued under shallow marine conditions throughout the Paleozoic and Mesozoic Eras., and the former considered it to be oceanic and the latter epicontinental which transgressed and regressed frequently. In such a set up there was no place for isolated seas, although ephemeral islands appeared and disappeared. The long-living MalayYunnan Geosynclines', the Mongolian Geosynclines' that climaxed in the Variscan, the Tien-Shan Geosynclines' that lasted till the Triassic, and the Leh-Lhasa Geosynclines' that climaxed in the Early Tertiary, all appeared in the same epicontinental sea.

It seems likely that the entire Central Asia collected sediments of the order of $60-70 \mathrm{~km}$ in thickness since the Cambrian-Ordovician, without any major break anywhere. [37] recorded the existence of an 'almost continuous sequence from Precambrian to Cretaceous' in the MallaJohar area of the Himalayas that was undoubtedly a part of the vast basin. Similarly, [38, 39] concluded that "from Precambrian to Upper Cretaceous or Middle Eocene is a period of sedimentation and epeirogenesis in Nepal
Himalayas. The sedimentation is of epicontinental type, characterized by a platform". Indeed, no evidence of a subduction zone that could have swallowed thousands of kilometers of oceanic crust exists anywhere. Moreover, realizing the double thickness of the sediments in the Tibet area, it was suggested that it must be the consequence of the under thrusting of Indian Plate which received ready acceptance in the absence of any alternative explanation. However, thicknesses of the same order seemingly appear in the Pamir area where no underthrusting is envisaged, as also immediately to the south of the so-called Indus-Tsangpo Suture Zone [40, 41]. In fact, thicknesses decreased progressively southward, yet are still of the order of $50 \mathrm{~km}$ immediately to the north of Mount Everest. It is surprising that these unusual thicknesses, as anomalous as those of the Tibetan area, don't seem to have properly attended under plate tectonic model of underthrusting and double thickness concept. Thicknesses of the order of 60-65 km exist over an extensive area in the Andes, but thrusting of a plate underneath another has not been envisaged. Doubling of crustal thickness below Tibet cannot explain by subduction of the Indian plate. A lighter continental crust cannot subduct. Even the supposedly oceanic crust of Tethys could not do so. Addition to thickness by subduction would require a lowangle movement of one plate to another, whereas subduction is a "high angle" process. A detailed study of seismic surface waves across north-central Tibet carried out by [42] reveals a distinctly thinner crust than that beneath southern and northernmost Tibet argues against underthrusting of India beneath all of Tibet have taken place. And, [9] based on data from Tibet, the Himalayas and China, too, discussed arguments for and against the underthrusting of Greater India beneath Eurasia, crustal shortening and thickening and eastward lateral extrusion models for the northward motion of Greater India into Eurasia and concluded that models advocating underthrusting and lateral extrusion are untenable. In the author's opinion the unique thickness of the crust was perhaps the consequence of a quiet, progressive downwrapping of the basin from Ordovician to the Triassic or may be Cretaceous. The beds remain undisturbed and an immense thickness accumulated over the vast area, covering the whole of Tibet and parts of India and China.

Significantly, no geosynclines presently exist over any part of the Earth's surface, and their disappearance seems to have coincided with the appearance of the oceans, i.e., the breakup of Pangaea. It appears that during the progressive expansion of the Earth vast rift valleys are formed where sediments accumulated as geosynclines. The expansion is now being absorbed by the mid-oceanic ridges. Existing on all the continents in the Archaean and Precambrian, sometimes two or three at a time in the area of either of the present continents, and seem to have decreased progressively since the Triassic, when the mid-oceanic ridges first appeared, till the same finally disappeared in the Tertiary times

\subsection{Paleontological Evidence}

Paleontology has played a vital role in paleogeographic 
reconstruction specially Gondwana configuration and extent. $[34,43]$ have pointed out that the faunal and floral distributions throughout the Earth's history were undoubtedly cosmopolitan, and no continental landmass could escape the migrating fauna and flora from one part to another ever since life-forms appeared. [44, p. 112] focused the Temnospondyli that evolved rapidly in the Permian and Triassic of Tasmania and confirmed that 'knowledge presently available supports the view that overland was the means of their worldwide distribution (italics by the present authors). He further suggested that remarkably the Parotosaurus, which was known from Germany, United States, the U.S.S.R, South Africa and Australia, provided a fine example of this cosmopolitanism. In the Triassic of U.S.S.R there are South African Therapsids, Cynodonts, Proterosuchians, Saurichia, etc., and even though only on general level, it would be difficult to explain without a direct land connection. Most significant is the presence of numerous specimens of reptiles of the Lystrosaurus zone of South Africa in China, Proterosuchus, Erythrosuchus and Lystrosaurus. Lystrosaurus is known also from Indo-China, Antarctica and Eastern Europe. Obviously, at least Lystrosaurus and Cynognathus must have roamed from South America and Antarctica through South and East Africa, and India to IndoChina and on to Shansi and Sinkiang provinces, whereas Erythrosuchus was present in U.S.S.R, as well as South Africa and China. These faunal evidences, therefore, do not justify the existence of the oceanic Tethys between Gondwanaland and the northern continents and rules out collision. In addition, some Triassic fossil of Tribosphenic mammals have been found in Madagascar sediments [45]. These finding judged surprising because these are located in the Southern Hemisphere, the Northern one long being supposed to be the region of the Tribosphenic mammals. Many other finding from South America, Africa and Australia are confirming the wider distribution of Tribosphenic mammals and the conceptually untenable idea of a large Tethys Sea separating Laurasia and Gondwana. These discoveries, besides the accumulating fossil evidence of Cretaceous Asian and Gondwanian mammals of India [46] support the above inference. It is, therefore, not surprising that [47] stated "except for the non-appearance of Phytosaurus in South Africa and South America, there is no marked contrast between the reptile faunas of Gondwanaland and Laurasia", and seems to be the possibility of extensive land-connections. [48] insisted that substantial new data from Permian-Triassic of India clearly reveals the presence of almost all the forms in the Permian-Triassic sediments of Indian Peninsular which are enlisted by [49] to exclusively European or local elements in the Salt Range mioflora. [35, p. 655] agreed that the Stepanoviella occurs on both the northern and the southern Xizang giving evidence of "a common bio-facies province". [50] pointed out that "Upper Triassic vertebrate families in Laurasia (28) and Gondwanaland (25) were common by $76 \%$. In Lower Triassic, the freshwater amphibians (6 families) and freshwater (2 families) and terrestrial (6 families) reptiles has worldwide distribution, an impossible preposition with the present distribution of continents'. It is more likely that there was no intervening barrier that could prevent migration of all life-forms - vertebrates, marine invertebrates, plants, freshwater fauna, and even insects from one landmass to another. It is therefore suggested that at least till the Triassic there were no oceanic deeps separating one continent from another, i.e., there was the only one continent on the Earth, Pangaea whose break up completed in the Cretaceous. [51] opined that with the discovery of Lystrosaurus in Antarctica almost identical with Lystrosaurus murrayi of South Africa, continental drift would pass from the realm of probability into that of almost complete certainty for it meant that there was no ocean to separate these continents. If the discovery of just one fossil specimen could force for a sudden change from outright anti-continental drift to pro-continental drift, what will be the fate of the well established distribution of scores of forms of plants, marine vertebrate (including ammonites that cannot cross oceanic deeps), vertebrate fresh water fauna, even insects and micro floras.

Paleofloristic Evidence: A review on the Paleobotanical evidence has demonstrated that plants Gangamopteris, Glossopteris, Vertebraria, Pecopteris, Dicroidium, and Pterophyllum etc, were common to Gondwanaland, on the one hand, and the northern landmasses, Laurasia, Angaraland and Cathaysia, on the other, some occurring more or less simultaneously in more than two or three localities. Thus, for instance Gangamopteris and Glossopteris the most characteristic of the Lower Permian flora appeared in Gondwanaland and they seem to have reached the northern landmasses in the Upper Permian. And similarly in the opposite direction, the northern types of plants seem to indicate a slighter older age when found in the Gondwana assemblages across the oceanic Tethys. This would suggest migration in the two directions. And therefore, the very concept of floral provinces having existed appears to have been invalidated.

Similarly, Gondwana plant fossils have been reported from some localities in Himalayas, China, Yunnan, Tibet [52, 53, 54], and plant fossils characteristics of the Jurassic of Peninsular India were discovered in Ladakh, from the north of the so called Indus Suture Zone [55]. Earlier, in the Carboniferous, Rhacopteris, Sigillaria and Lepidodendron etc, were present in Australia, South America, as well as in Laurasia, whereas the Triassic floras, with Cladophlebis, Gingkoites, and Sagenopteris etc. having been common to the northern and southern landmasses. And migration of plants would naturally mean a contiguity of land and thus there appears to be no escape from the conclusion that Pangaea existed as a single landmass. In the face of this, the assertion by [16], that there seems to be no unambiguous paleofloristic proof of the Gondwana origin of the Lhasa block and [14], in a classic volte face, admit that Lhasa belonged to Gondwanaland, and their earlier views that Gondwanaland in Tibet has been underthrust below Angaraland or that the Indus-Zangpo (Tsangpo) line marked the "suture zone" of the northern and the southern 
landmasses were untenable [see also; 54].

\section{Paleoclimatic Evidence}

Convincing arguments advanced in the past for treating Gondwanaland and Laurasia as two separated landmasses was that the former was known to have been extensively and repeatedly glaciated in the Permian, while the latter was enjoying a tropical climate. An ocean had to be made to intervene to justify these climatic differences. With the discovery of Lower Permian glacial deposits in Verkhoyansk, Siberia, Tibet and China in northern continents eliminated the need to have ocean separating the two landmasses. Equally significant is the fact that Gondwana glacial deposits have been reported from Everest, Myanmar, Spiti, Nepal, and eastern Kashmir, all from the so-called "Tethyan Zone" of the Himalayas, and all lying well to the north of the Main Boundary Fault, that was considered to be the junction of the northern and the Gondwana continents till the equally hypothetical "Indus-Tsangpo Suture Zone" was accorded this dubious honor.

Palynological data from the tuffaceous shale associated with Dras Volcanic complex near Shergol (Ladakh) indicate proximity of this belt to the Indian subcontinent. Based on a Palynological assemblage dominated by palm pollen particularly Nipa and rare Ephedra, [56] suggests that both areas had a tropical to sub-tropical climate during the Late Cretaceous-Paleocene. Climatic similarities prevailed even in the Middle Pleistocene. Terrestrial life form on either side of the Indus-Tsangpo Suture Zone maintained family affinities for a long time [57, 58, and 59]. A large variety of land vertebrates comprising bison, deer, giraffe, hippopotamus, rhinoceros, Equus etc. and their similarity in the Siwalik and Tibetan basins lead to the inevitable conclusion that the Tibetan land was at low elevation which permitted free migration paths to the animals during Oligocene through at least Early Pliocene time. Late Pleistocene strata in eastern Tibet have yielded fossil Bibosan animal found in low altitude tropic today. Tibetan climate had remained hospitable enough for the Stone Age man whose archaeological remains are found there [60]. It means that paleoclimatic continuity was maintained over this landmass of India and Tibet from the Paleozoic through Cenozoic to the Pleistocene Epoch. Indeed modern global plate tectonics is certainly incapable to explaining it, and the phenomenon can be explained by the expanding Earth concept.

\section{Paleopole, Paleogravity and Earth's Diameter}

The Cambrian North and South Poles, according to the paleomagnetic data were, respectively situated in the present Indian Ocean and north-west Morocco, and gradually migrated northward thereafter. Paleo magnetically located North Pole moved simultaneously from Antarctica to Verkhoyansk area in Siberia during Permian times. On the other hand, the South Pole migrated from northwest Africa in the Cambrian, and was to the southeast of Natal in the Permian. Indeed, the paleomagnetic pole position for the Permian is based on Permian rocks of South Africa, and the two belong to exactly the same age, and apparently coincide. Thus, these pole positions during Permian times have been $55-60 \%$ of the present diameter, allowing for the differences in paleo magnetically determined polar positions by different workers. Both the Cambrian poles can be similarly identified with reasonable confidence and yield a diameter of about $50 \%$ of the present. These data suggests that the Earth has expended progressively since the Permian, may be earlier, and it would appear that in about $250 \mathrm{Ma}$ since the Permian expansion was much more than in the immediately prior to $250 \mathrm{Ma}$ since Cambrian. It would, therefore, favor that the rate of expansion has accelerated, and maybe it is progressively accelerating.

Recently, the rate of change is interpreted either as "plate" movements or Earth-radius change by the current NASA intercontinental chord measurements. On the data published so far by NASA, the rate of increase of Earth radius comes out at $2.4 \pm 0.8 \mathrm{~cm} /$ year means $17.6 \pm 5.0 \mathrm{~cm} /$ year increase in circumference, which would mean between 12,600 and $22,600 \mathrm{~km}$ increase in all great circles since the Middle Cretaceous, and account for all new ocean floor growth at the spreading ridges since the Early Cretaceous without any subduction supporting [61] contention for slow expansion until the Mesozoic, but very rapid expansion since Middle Cretaceous. According to the space geodetic data recorded globally and gravimetric observations support the aforesaid conclusion that Earth is expanding at a rate of $0.24 \pm 0.05$ $\mathrm{mm} /$ year in recent two decades [62].

The concept of Expanding Earth is recently supported by [63 and 64] and they contemplating decline in the gravitational constant and surface gravity during Precambrian up to about one third of the present value and about one half of the present value during the Mesozoic. The Mesozoic was off course an Era of dinosaurs, those very large (e.g. Diplodocus and Brontosaurus), very long bodied creatures (e.g. Quetzalcoatlus) that could very well have benefitted from a much lower surface gravity. By Middle Cretaceous Triceratops and Tyrannosaurus dinosaurs were much smaller, although still huge. On the other hand birds become lighter from the heavy-boned Archaeopteryx and bird-like Iguanodon to much lighter modern birds. [65 p. 131] suggested that Mesozoic dinosaurs could not have existed with present surface gravity nor would have bat like Pterosaurs with $12 \mathrm{~m}$ wing spans. There were giant insects that were all much longer than we would expect. In addition to above, the vegetal realm also suggests a progressive decrease of the dimensions of the plants from angiosperm to gymnosperm and so on decreased in size on the average through Mesozoic and Cenozoic, and this can be undoubtedly interpreted as an evidence of lesser Mesozoic gravity [63]. 
These lines of evidence leave one with no doubt that a progressive increasing of gravity has been a fundamental derive factor in biological and paleontological evolution.

\section{Discussion}

Of late, the concept of an oceanic Tethys gained momentum when a wide, triangular oceanic gulf appeared on the east coast in the Pangaea Supercontinent, placed in the Chinese region, tapering down towards the west to near the Black Sea/ Spain area [66, 67 and 68] and others. [67] and recently [60] admittedly tried to assemble Pangaea and could not make this triangular ocean disappear on a globe of the present diameter. They further realized that it had no place in a true Pangaea, which means that the continental crust covered the entire globe. On the other hand, by the Middle Permian the fauna of the Himalayas and Tibet were so identical at the generic and species level with those of surrounding regions that the wide Tethyan gulf of many reconstructions hardly seems possible. Many workers have pointed out the evidence against such wide gulf and indicated that it was not based on geological data but resulted from fitting South America and South Africa, thus either pulling all of Asia down to the south or making some arbitrary split to form a wide eastward facing Tethyan gulf. [34]'s paleogeographic maps demonstrated that on this assembly fresh water and shallow marine deposits occurred all over the landmass with no indication of oceanic deposits anywhere. There was undoubted continuity of landmass that was broken occasionally by local development of geosynclines. Plate tectonic model, however, accepted this triangular ocean without any reservation and designated it the 'Paleotethys'. Nevertheless, [69, p. 250], based on sea-floor spreading data, concluded that, "the evidence for a former Tethyan Ocean between Gondwanaland and Laurasia is non-existent", and that there is "no need to infer the presence of Tethyan oceanic crust north of Greater India".

Later on, in the plate tectonic concept suggestion is given that Greater India had separated from the northern continents in the Late Paleozoic and moved to the southern hemisphere near Madagascar and then returned, beginning in the Late Mesozoic, to its original position to collide with Angaraland along the Indus-Tsangpo Suture zone (ITSZ). It raises a question that what was the 'original' position of the Greater Indian subcontinent because in all the reconstructions India appears to the south of the paleotethys and Tibet to its north. However, in the reconstruction of Pangaea, Antarctica appears to the south of India and it is not known as to what happened to this vast continent when India suddenly started moving southward, nor is the mechanism responsible for the southward movement of India. Moreover, the ocean that came into being when India started moving southward has been identified as 'Neotethys'. But a mid-oceanic ridge must have appeared in the area, because scientifically there was no other agency responsible for continental migration. The collision along the Indus-Tsangpo Suture Zone resulted in the ophiolites being obducted at the time of the collision in the
Oligocene-Miocene, and thereafter the Indian plate is supposed to be progressively underthrusting the Tibetan plate. However, as pointed out earlier, the ophiolites are of two different ages, having been erupted in two phases, Upper Jurassic to Lowest Cretaceous and then again in Lower Cretaceous. It makes the ophiolites about a hundred million years older than the presumed collision and no suitable explanation is available for such an anomaly. In view of the above evidence, [70] asserted that 'the ophiolite was probably obducted during Eocene', and just because it fits in with the hypothesis they are wedded to time of collision. The other contradiction of the obducted ocean concept is that there seems to be no doubt about the fact that far from being obducted ocean bottom rocks, which should have been solid and cold, these ophiolites were in a highly molten state and the Lower Cretaceous emplacement had come up from a depth of $80-140 \mathrm{~km}$. It has apparently resulted in extensive crystal settling, producing acidic rocks at the top and ultrabasic rocks at the bottom of every exposure. Had there been formed of oceanic crust, in the process of continental collision, there would, perhaps, not have been two separate emplacements nor they would not have suggested high temperature and pressure in the region of their origin. More significantly geosynclines existed across the so-called IndusTsangpo Suture Zone, thus covering both the plates; since the Triassic and it culminated in the Tertiary [71, p. 49 and 72] insists that "the Permo-Carboniferous system occurring on both sides of Yarlu-Zhangbo River may be regarded as forming part of a single platform domain". Similarly [73] agreed that Tibet has a crustal thickness of $70 \mathrm{~km}$, but there is no "twin layer crustal structure" i.e. a crustal block does not underlie another. He further considered the YarlungTsangpo feature as a 'fault zone', and [74] believed that so called suture is in fact 'a propagation ridge and therefore 'constraints the plate tectonic model of Himalayan evolution'. Thus, it would appear that the former relationship of India and Tibet is borne out by:

1). The occurrence of glacial deposits of Upper Carboniferous in Tibet with the provenance of glacial debris in the south from the Indian continent indicates that India was in its present location with sialic crust continuing from Peninsular India to northern Tibet. It is therefore suggested that the paleomagnetic evidences need to be re-checked and reinterpreted. May be the data merely suggest that the North Pole was rapidly moving northward all the time, and has accordingly been recorded in the Indian rocks.

2). The occurrence of Lower Permian vertebrate fauna in Kashmir with European affinities indicates that India and the northern continents were not separated even by a narrow intervening ocean. Therefore, the imaginary barrier, an oceanic Tethys that had been presumed between Gondwanaland and the northern continents is not tenable in the Paleozoic or Mesozoic.

3). The Lystrosaurus fauna, reported from Antarctica, South Africa, East Africa, Peninsular India, Sinkiang and Shansi in China and Indo-China supports a wide, 
perpetual land connection between the southern and the northern continents in the Lower Triassic. Of particular significance is the distribution of Phytosaurus, particularly the Archaegosaurus. Being semi-aquatic having the ecological preference of crocodiles, i.e. by and large they lived in fresh water rivers and lakes, and yet they were present simultaneously in South Africa, India, Central Asia and Western Europe.

4). It is significant that when Greater India is supposed to have been migrating from southern to the northern hemisphere surrounded by oceanic deep on all sides, it carried a vertebrate fauna identical with that of Africa. There is no suitable explanation as to how the fauna managed to crossover. It was possible only if Greater India was in its present location and had proper and well established land-bridge connecting it to Africa all the time.

5). Similarly, [75] have demonstrated the lack of endemism in Indian flora and fauna from the Late Paleozoic to the Quaternary, which shows that India was never as an island continent. [76] agreed that available Late Triassic nannofossils evidence does not support the separation of the Indian Plate from Pangaea till it drifted from Africa-Madagascar during Jurassic.

$6)$. The ophiolites in the suture zone have resulted in thermal metamorphism of the host rocks i.e. the Indian and the Tibetan Plates showing chilled margin. It would have been impossible if India was not in its present position and instead was in the southern hemisphere as envisaged by the plate tectonic model.

7). The two magmas obviously tapped different levels of the mantle and are certainly not obducted ocean floor material. The two emplacements are confined within two faults dipping at $60^{\circ}$ towards each other in the rift valley. Also the magma emplacement started about 100 Ma before the presumed suturing.

8). The development the Lhasa-Leh geosynclines in the Late Mesozoic, maturing in the Early Tertiary, and cutting across the Indus-Tsangpo Suture Zone (ITSZ) extending, into Ladakh indicates that there was no ocean in the area between Tibet and India throughout the Tertiary.

The above arguments do not favor an oceanic Tethys in between India and Tibet and the Epicontinental Sea that extended from one end to the other can, nevertheless, be identified as the Tethys. The Pacific Ocean, too, was probably non-existent till at least the end of Permian, or else it was exceedingly narrow to allow Gigantopteris to cross from China to western North America. The existence of $1600 \mathrm{~m}$ thick marine glacial deposits in northern Tibet and adjoining areas, covering thousands of sq. $\mathrm{km}$. is suggestive an ice cap in Peninsular India for millions of years. Glaciers must have been emanated in all directions, some continuing on the continental crust to become icebergs in the Tethys to the north. They must have cut deep channels in the area of the present Gangetic basin and Himalayas as well before joining the Tethys. As the ice cap receded westward, marine fauna from the sea moved into the Gondwana basins along these deep channels. The marine fauna of Umaria and Manendragarh presumably came via the main stream flowing northwestwards, as indicated by the paleoflow directions [10] ruling out the paleogeographic map of [35] [figure. 6].

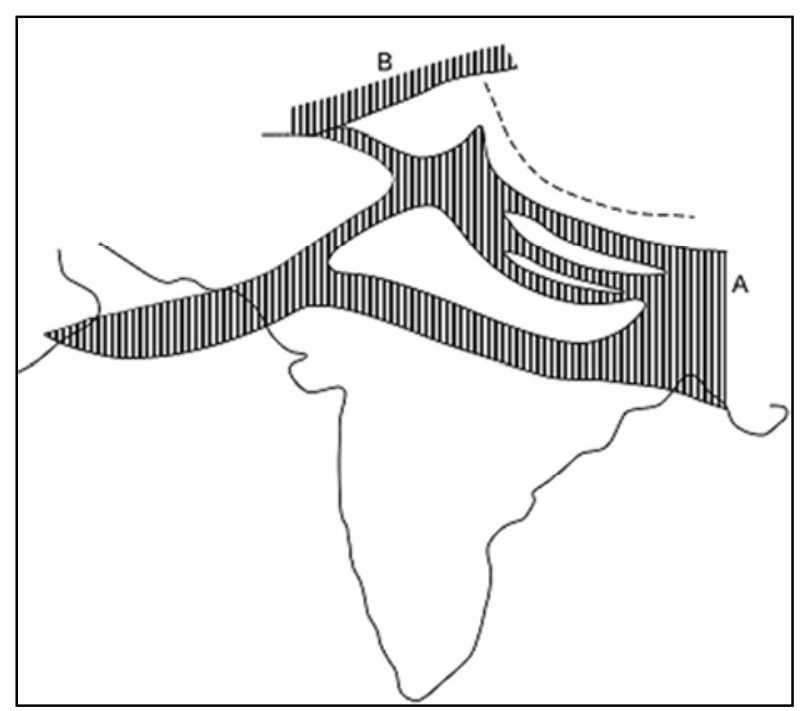

Figure 6. Distribution of land and sea in the Peri-Gondwana of the Indian Subcontinent during Permian. A=Kshir Sagar; B= Tethys [35].

Plate tectonic hypothesis suggests that the Himalayas have been uplifted as a consequence of the collision of the Indian and Tibetan Plates, and that the Tibetan plateau resulted from the over-riding of the latter over the former. Intense compression, then, should exist over the Indian sub-continent, as also over the Tibetan plateau. This, however, is not so, and presently available evidence bespeak of strong tension over the Indian block as discussed by [34]. Yet, the fact that over larger areas, rocks were not strongly folded did not appear to be reconciled either with subduction or with the collision concepts. The only evidence of compression found over the Tibetan plateau was some mild folding in the Cretaceous, i.e. from long before the much talked of collision and suturing. On the other hand, the beds on the two sides of the Indus-Tsangpo Suture Zone, where the collision is believed to have taken place, are perfectly horizontal. Indeed, there is no suitable explanation for this remarkable unparallel uplift that has occurred about hundred kilometers away or more. Also, the fact that the Himalayan uplift had been initiated in the Upper Cretaceous, millions of years before the collision just when the Indian plate had started its northward journey from near Madagascar. The major uplift is placed in the Eocene, when India must still have been far away from the site of the collision.

The foregoing discussion evidently concludes that the chances of separation of Indian subcontinent from southern hemisphere and its northward journey to return to original position are remote. It is further suggested that Du Toit's contention of an independent Gondwanaland at the South Pole separated from the northern continent/continents by a wide oceanic Tethys needs reappraisal and thorough revision and reappraisal. 
To sum up the paleontological, paleoclimatic, geological, geodetic and Paleogravity evidently support the concept of expanding Earth and do not favors the collision and underthrusting model of plate tectonics. The expanding Earth phenomenon is recently re-investigated in light of new evidence by several workers $[43,62,77,78,79,80,81,82$, and 83].

\section{Conclusions}

The various geological, paleontological and paleogeographic evidences related to northern margin of Indian plate and Indo-Tsangpo suture suggest that there is no place for an oceanic Tethys in any dimension and shape, and India and Africa were always in their present locations as part of Pangaea. Unassailable evidences from Carboniferous to Cretaceous for each geological age suggest that India continued into the northern continents through Tibet on the one hand and southern continents on the other.

The double thickness of the crust in Tibet suggesting that India is progressively under-thrusting is not justified because such unusual thickness continues to the south of the so-called Indus-Tsangpo Suture Zone, and thereafter, decreases gradually up to the Himalayas and farther south indicating the progressive shallowing of the epicontinental Tethys southward. Also it was obviously not possible for the Indian plate to pass through an $8-20 \mathrm{~km}$ thick wall of ophiolites between the two plates formed at the time of collision. And, the unique thickness of the crust was the consequence of a quiet, progressive down-wrapping of the basin from the Ordovician to the Triassic or may be Cretaceous.

The position of the two poles for the Cambrian and the Permian suggest unequivocally that the Earth was of smaller diameter and is expanding progressively. On the other hand [63] have concluded from study that reduced Earth radius with constant Earth mass implies higher surface gravity, and the much reduced surface gravity is essential for dinosaurs to grow in gigantic proportions, an important aspect that provides support for the Expanding Earth. Indeed, the mass of the Earth must have been less during Mesozoic. Both geodetic and gravimetric observations too support the aforesaid conclusion.

The Lower Permian vertebrate of Kashmir being identical with that of Europe further strengthens the contention of continuity of landmasses. The well-known Lystrosaurus fauna bespeaks unequivocally the same for the Triassic, and the ophiolites bear it for the Jurassic-Cretaceous. The development of a eugeosyncline extending from Ladakh to Tibet and affecting both the flanks of the suture zone, confirming that the two plates were together throughout Tertiary and the Indus-Tsangpo Suture is cut through by a number of Quaternary rift valleys and normal faults indicating that they were not separated. If so, then when was India in the southern hemisphere and migrated all the way from there to collide with Tibet? It is to conclude that Paleogravity, geodetic and supporting geological and paleontological and paleoclimatic constraints rule out the collision and underthrusting of Indian plate and evidently support Earth expansion model.

\section{References}

[1] Du Toit, A. L., 1937. Our Wandering Continents. Oliver Boyd, $377 \mathrm{p}$.

[2] Ahmad, F., 1960. Glaciations' and Gondwanaland. Rec. Geol. Surv. India. 86, 651-674.

[3] Han Tonglin and Wang Naiwen, 1983. Carboniferous glacial marine deposits in northern Xizang. Bull. Chinese Acad. Geol. Sci., (Abstract), 47-48.

[4] Hongfu Yin, 1994. The paleobiogeography of China. Oxford Univ. Press, 370p.

[5] Xiaochi, J., 2002. Permo-Carboniferous sequences of Gondwanic affinity in southwest China and their paleogeographic implications. Jour. Asian Earth Sci., 20, 633-646.

[6] Meyerhoff, A. A., Kamen Kaye, M., Chin Chen, Tanner, I., 2012. China-Stratigraphy, Paleogeography and tectonics. Springer Geosciences, 188p.

[7] Chang, Chengfa and 24 Others. 1986. Preliminary conclusions of the Royal Society and Academia Sinicia 1985 Geotraverses of Tibet. Nature, 323, 501-507.

[8] Shenglong, L., and 4 Others. 2015. Age of the Purported Zhanjiang Formation in Gerze County, Tibet: A new understanding and its significance. Acta Geologica Sinica, 89, 1673-1789.

[9] Dewey, J. F., Shackleton, R. M. Chang Chengfa and SunYiyin. 1988. The tectonic evolution of the Tibetan plateau. Phil. Trans. Royal Soc. London, 327, 379-413.

[10] Casshyap, S. M., Tewari, R. C. and Srivastava, V. K., 1993. Origin and evolution of intracratonic Gondwana basins of India and their depositional limits in relation to Narmada-Son lineament In: Rifted basins and Aulocogens: Geological and Geophysical Approach. Gyanodaya Prakashan, Nainital, 200-214.

[11] Sun Dong-Li, 1993. On the Permian biogeographic boundaries between Gondwana and Eurasia in Tibet, China as the eastern section of Tethys. Paleogeography, Paleoclimatology, Paleoecology, 100, 59-77.

[12] Upadhyay, R., and 6 Others. 1999. Discovery of Gondwana plant fossils and palynomorphs of Late Asselian (Early Permian) age in the Karakoram Block. Terra Nova, 11, 278-283.

[13] Haung Jiqing, 1984. Preliminary analysis of the TethysHimalaya tectonic domain. Acta Geologica Sinica, 1, 2-17.

[14] Tapponnier, P., Mercier, J. C. and Proust, F., 1981. The Tibetan side of India-Eurasia collision. Nature, 294, 405-410.

[15] Acharyya, S. K., 1990. Pan-Indian Gondwana plate breaks up and evolution of the northern and eastern collision margins of the Indian Plate. Jour. Himalayan Geology, 1, 75-92.

[16] Allegre, C. J. and 34 Others. 1984. Structure and evolution of the Himalayan Tibet orogenic belt. Nature, 307, 17-22.

[17] Wang, J. G., and 6 Others. 2016. Upper Triassic turbidities of the northern Tethyan Himalaya: the terminal of a sediment routing system sourced in the Gondwanide Orogen. Gondwana Research, 34, 84-98. 
[18] Ahmad, F. and Khan, Z. A., 1993. Marine incursions in Gondwana Supergroup in Central India. Gondwana Geological Magazine, Special volume, 1-7.

[19] Veevers, J. J. and Tewari, R. C., 1995. Gondwana master basin of Peninsular India in between Tethys and Interior of Gondwanaland Province of Pangaea. Mem. Geol. Soc. America No. 187, 72p.

[20] Najman, Y., and 9 others. 2010. Timing of India-Asia collision: Geological, biostratigraphic and paleomagnetic constraints. Jour. Geophysical Research, 115, 1978-2012.

[21] Jain, A. K., and 9 others. 2012. Evolution of the Himalaya. Proceedings Indian National Science Academy, 78, 259-275.

[22] $\mathrm{Hu}, \mathrm{X}$., and 5 others. 2016. The timing of India-Asia collision onset - Fact, theories, controversies. Earth Science Review, 160, 264-299.

[23] Liang Rixuan and Bai Wanji, 1984. Genesis of ultramafic rocks in Yarlung-Zhangbo ophiolitic belt. Inter. Sym. Himalayan Geol., (Abstract), 117-118.

[24] Bai, W. J., and 8 Others. 2000. The PGE and base metal alloys in the podiform chromitites of the Luobusa ophiolite, southern Tibet. Canadian Mineralogist, 38, 585-298.

[25] Deng Wanming, 1980. Trace element geochemistry of the ophiolites complex in Xigaze (Tibet). Sino-French Coop. Investigation of Himalaya. (Abstract), 236-237.

[26] Chang, Chengfa and Chen, Hsi-lan, 1983. Some tectonic features of the Mt. Jolmo-Lungma area, southern Tibet, China. Sci. Sinicia, 16, 257-265.

[27] Raiverman, R., 2002. Foreland sedimentation in Himalayan tectonic regimen: A relook at the orogenic process. BSMPS Publ., New Delhi, 378p.

[28] Xiao Xuchang, 1980. The Xigaze ophiolite of southern Xizang (Tibet) and its relevant tectonic problems. Sino-French Coop. Investigation Himalaya, 164-168.

[29] Yin, J. Deng, W. Wen, S. and Sun, D., 1998. Pre-Jurassic tectonic evolution of the intermediate transitional blocks of the Qinghai-Tibet plateau and adjacent areas. In: Pan, Y. and Kong, $\mathrm{X}$ (Eds). Lithosphere structure, Evolution and Dynamics of the Qinghai-Tibet plateau. Guangdong Science \& technology Press, 217-232.

[30] Klootwijk, C. J., 1987. Greater India's northern margin paleomagnetic evidence for large scale continental subduction. Proc. Inter. Symp., Shallow Tethys 2 (Abstract), 259.

[31] Radhakrishmurty, C., and Subbarao, K. V., 1990. Paleomagnetism and rock magnetism of the Deccan Traps. Proc. Ind. National Science Academy, 99, 669-680.

[32] Verma, R. K., and Hari Narain, 2013. Paleomagnetic studies of Indian rocks and continental drift. In: Knopoff, L. Drake, C. L. and Hart, P. J. (Eds.). The Crust and Upper mantle of the Pacific area, 189-197.

[33] Molnar, P., 2016. The Paleoposition of India. Jour. Southeast Asian Earth Science, 1, 145-189.

[34] Ahmad, F., 1981. Late Paleozoic and Early Mesozoic paleogeography of the Tethys region. In: Carey, S. W. (Ed), Expanding Earth Symposium, University Tasmania, Sydney, 131-145.
[35] Kapoor, H. M., and Maheshwari, H. K., 1991. Early Permian paleogeography of the Peri-Gondwana in the Indian Segment. Current Science, 61, 648-653.

[36] Crawford, A. R., 1979. A Greater Gondwanaland. Science, $184,1179-1181$.

[37] Kumar, S., Singh, I. B., and Singh, S. K., 1977. Lithostratigraphy, structure, depositional environment, paleocurrent and trace fossils of the Tethyan sediments of Malla-Johar area, Pithoragarh-Chamoli Dist. U. P. Jour. Paleontology Soc. India, 20, 396-435.

[38] Colchen, M., 1975. Paleogeography and structural evolution of the Tibetan area of Nepal Himalayas. Himalayan Geol., 5, 83-103.

[39] Garzione, C. N., Dettman, D. L., Quade, J., De Calles, P. G. and Butter, R. F., 2000. High times on the Tibetan plateau: Paleo-elevation of the Thakkhola Graben, Nepal. Geology, 28, 339-342.

[40] Zhao, W. J. and Nelson, K. D., 1993. Deep seismic reflection evidence for continental underthrusting beneath the southern Tibet. Nature, 366, 557-559.

[41] Shin, Y. H., and 4 others. 2009. Moho undulations beneath Tibet from GRACE- integrated gravity data. Intern. Jour. Geophysics, 170, 971-985.

[42] Brandon, C. and Romanowicz, B., 1986. A 'no lid' zone in the central Charg-Thang platform of Tibet: Evidence from pure path phase velocity measurements of long period Rayleigh wave. Jour. Geophy. Research, 91, 6547-6564.

[43] Khan, Z. A. and Tewari, R. C., 2016a. The facts and fictions of the oceanic Tethys concept. Jour. Geosciences, 1, 12-41.

[44] Cosgriff, J. W., 1974. Lower Triassic Temnospondyli of Tasmania. Geol. Soc. Amer. Special Paper No. 149. 134p.

[45] Flynn, J. J. and 6 others 1999. A Triassic fauna from Madagascar, including Early Dinosaurs. Science, v. 286, p. 763-765.

[46] Rana, R. S. and Wilson, G. P., 2003. New Late Cretaceous mammals from the Intertrappean beds of Rangapur, India and paleobiographic framework. Acta Paleontologica Pol., 48, 331-348.

[47] Kemp, T. S., 2005. The Origin and Evolution of Mammals. Oxford Unvi. Press, Oxford, 331p.

[48] Tiwari, R. S., Singh, V., Kumar, S., and Singh, I. B., 1984. Palynological studies of the Tethyan sequence in Malla-Johar area, India. Paleobotanist, 32, 341-367.

[49] Balme, B. E., 1995. Fossil in situ spores and pollen grains: an annotated catalogue. Review Paleobotany and Palynology, 87, 81-324.

[50] Shields, O., 1988, Theories of the Earth and Universe: a history of Dogma in the Earth Sciences. Cladistics, 4, 407-412.

[51] Colbert, E. M., 1979. Gondwana vertebrates In: Laskar, B. and Raja Rao C. S. (eds.) $4^{\text {th }}$. International Gondwana Symp., Geol. Surv. India, 135-143.

[52] Fan Yingnian, 1984. Division of zoogeographical provinces by Permo-Carboniferous corals in Xizang (Tibet). Intern. Geol. Symp. Himalaya, 1, 1-2 (abstract). 
[53] Sun Dong-Li, 1993. On the Permian biogeographic boundaries between Gondwana and Eurasia in Tibet, China as the eastern section of Tethys. Paleogeography, Paleoclimatology, Paleoecology, 100, 59-77.

[54] Xiaochi, J. Huang, H. Shi, Y. and Zhan, L., 2011. Lithologic boundaries in Permian post-glacial sediments of the Gondwana affinity regions of China: Typical sections, Age range and correlation. Acta Geologica Sinica, 85, 373-386.

[55] Sharma, R. K. Gupta, R. K. and Sah, S. C. D., 1980. Discovery of upper Gondwana plants north of Indus Suture Zone, Ladakh. Current Science, 49, 470-471.

[56] Mathur, Y. K. and Jain, A. K., 1980. Palynology and the age of the Dras Volcanic near Shergol, Ladakh, Jammu \& Kashmir, India. Geosciences' Journal, 1, 55-74.

[57] Norin, E., 1946. Geological expedition in Western Tibet. Report Sino-Swedish Expedition, Stockholm, 229p.

[58] Shackleton, R. M. and Chang Chengfa, 1988. Cenozoic uplift and deformation of the Tibetan plateau: the geomorphologic evidence. Phil. Trans. Royal Soc. London, A327, 365-377.

[59] Wang, X. Qiu, Z. and Li, Q., 2007. Vertebrate paleontology, Biostratigraphy, chronology and paleo-environment of Qaidam basin in northern Tibet plateau. Plaeogeography, Paleoclimatology, Paleoecology, 234, 363-385.

[60] Valdiya, K. S., 1993. Uplift and geomorphic rejuvenation of the Himalaya in the Quaternary Period. Current Science, 64, 873-885.

[61] Scalera, G., 2003. The Expanding Earth: some idea for the new millennium. In: G, Scalera and K. H. Jacob (Eds). Why Expanding Earth, Mining Industry Museum, Germany, 181232.

[62] Shen, W., and 3 Others, 2015. Evidences of expanding Earth from space-geodetic data over solid land and sea level rise in recent two decades. Geodesy and Geodynamics, 6, 248-252.

[63] Hurrell, S. W., 2011. Dinosaurs and the Expanding Earth. $3^{\text {rd }}$. Edition, One-off Publishing Com., Great Britain, 213p.

[64] Maxlow, J., 2014. On the origin of Continents and Oceans: A paradigm shift in understanding. Terella Press Australia. 260p.

[65] Carey, S. W., 2000. Earth, Universe and Cosmos. $2^{\text {nd }}$. Edition, School of Earth Sciences, Hobart, 258p.

[66] Smith, A. G. and Hallam, A., 1970. The fit of the southern continents. Nature, 225, 139-144.

[67] Carey, S. W., 1976. The expanding Earth. Elsevier. 488p.

[68] Scotose, C. R. and Mckerrow, W. S., 1990. Revised world maps and introduction. In: W. S. Mckerrow and C. R. Scotose (Eds). Paleozoic paleogeography and biogeography. Geological Soc. London Mem., 12, 1-21.
[69] Owen, H. G., 1976. Continental displacement and expansion of the Earth during the Mesozoic and Cenozoic. Phil. Trans. Royal Soc. London, 281, 223-291.

[70] Girardeau, J. and 4 Others, 1985. The Xainxa ultramafic rock central Tibet, China: Tectonic and geodynamic environment. Geology, 13, 330-333.

[71] Xu Baowen, Badengzhu and Zhang Haoyang, 1984. Is the suture zone between the Indian Plate and Eurasian plate in Xizang (Tibet)? Intern. Symp. Himalayan Geol., (Abstract), $48-50$.

[72] Xiao Xuchang, 1980. The Xigaze ophiolite of southern Xizang (Tibet) and its relevant tectonic problems. Sino-French Coop. Investigation Himalaya, 164-168

[73] Cui Zhuozhou, 1984. Research for formational mechanism of Qinghai-Xizang Tibet plateau. Intern. Symp. Himalayan Geol, (Abstract). 130-131.

[74] Gopel, C., Allegre, C. J., and Xu, R. H., 1984. Constraints on the origin of two Tibet ophiolites from $\mathrm{Pb}$ - isotopes: Intern. Symp. Geol. Himalaya, (Abstract), 2, 2.

[75] Chatterjee, S. and Hotton, N., 1986. The Paleoposition of India. Jour. Southeast Asian Earth Science. 1, 145-189.

[76] Rai, J., Upadhyay, R. and Sinha, A. K., 2004. First Late Triassic nannofossils record from Neo-Tethyan sediments of the Indus-Tsangpo Suture Zone, Ladakh Himalaya, India. Current Science, 86, 774-777.

[77] Scalera, G., 2006. TPW and polar motion as due to asymmetrical Earth expansion. In: G. Lavechia and G, Scalera (Eds). Frontier in Earth Sciences: New ideas and interpretation. Annals Geophysica, 49, 483-500

[78] Hurrell, S. W., 2012. Global expansion tectonics: A significant challenge for Physics. Proc. N P A, 9, 363-373.

[79] Hurrell, S. W., 2014. A new method to calculate Paleogravity using fossil feathers. N C G T, Jour., 2, 29-34.

[80] Maxlow, J., 2016. Is plate tectonic better suited to an increasing radius Earth model? Australian Institute of Geoscientists News, 39-43.

[81] Cwojdzinski, S., 2016. History of discussion selected aspects of the Earth expansion vs. Plate tectonics theories. Geological Soc. London, Sp. Pub., 442, 42p.

[82] Khan, Z. A. and Tewari, R. C., 2016. The concept of Gondwanaland and Pangaea: a reappraisal. Jour. Applied Geology and Geophysics, 4, 44-56.

[83] Khan, Z. A. and Tewari, R. C. and Hota, R. N., 2017. Problem in accepting plate tectonics and subduction as a mechanism of Himalayan evolution. Jour. Applied Geology and Geophysics, $5,81-100$. 